\title{
The Question of a Voice: With What Voice Will I Cry My Sad Fado?
}

\author{
Maria do Rosário Dias ${ }^{1,2}$, Nadia Pereira Simões ${ }^{2}$, Ana Ferreira ${ }^{2} \&$ Eva Coelho $^{2}$ \\ ${ }^{1}$ Egas Moniz - Cooperativa de Ensino Superior, CRL, Monte da Caparica, Portugal. \\ ${ }^{2}$ Egas Moniz - Centro de Investigação Multidisciplinar em Psicologia da Saúde. \\ Correspondence: Maria do Rosário Dias, Egas Moniz - Centro de Investigação Multidisciplinar em Psicologia da Saúde, \\ Campus da Granja, Monte da Caparica, 2829 - 511 Caparica, Portugal.
}

Received: August 15, 2016

doi:10.11114/ijsss.v4i10.1879
Accepted: August 29, 2016

Available online: September 13, 2016

URL: http://dx.doi.org/10.11114/ijsss.v4i10.1879

\begin{abstract}
Fado is a traditional Portuguese music genre whose lyrics are emotionally rich, often referring to fate, love, longing, death, abandonment and helplessness. By singing these feelings a national identity is reinforced, either by the transgenerationality of the pain portrayed in these songs, or by evoking unique and untranslatable Portuguese words, such as Saudade (homesickness with melancholy) or Fado (fate in a sad and insurmountable way). In this manuscript, the universe of Fado is described and linked to a psychoanalytic meaning, through analyzing the relation between Saudade and depressiveness, what feels like to be a Fadista or the sublimation of trauma through Fado, as a song, that has been inscribed by UNESCO, on the Representative List of the Intangible Cultural Heritage of Humanity in 2011.
\end{abstract}

Keywords: Fado, Saudade, trauma, depressiveness, voice.

\section{Introduction}

\section{Fa - do, (Latin fatum, -i, oracle, prediction, prophecy) \\ 1. Top Force believed to control all events.}

2. What has to happen independently of human will.

3. [Music] Portuguese folk song usually performed by a vocalist (singer), accompanied by Portuguese guitar and classical guitar.

(Dictionary of the Portuguese Language, 2006).

\section{Silence! : Fado Will Be Sung!}

Fado as a musical genre appeared in Lisbon in the 19th century in the neighborhoods of Alfama and Mouraria, and for its uniqueness, UNESCO has inscribed Fado on the Representative List of the Intangible Cultural Heritage of Humanity in 2011. The creation of Fado was linked to the urbanization process that took place across Portugal in the early 19th century, more specifically in Lisbon (Frydberg, 2010). During the renewal of Lisbon after the 1755's earthquake, the Alfama district was left out of the enlightenment urban plans of Marquis of Pombal and served for the relocation of the lower strata of the population. Fado has emerged then as a way of sharing feelings between people of the same community. It has emerged as a fusional and eclectic folk art, meant to elevate the harsh condition of the people. Nowadays, the disclosure of social inequality can still be found in the central structure of the narrative of the amateur Fado of Alfama; Both feelings of revolt against the rich and also envy for such a position. The lamentation over a life of poverty, insecurity and dependence can also be found in Fado's lyrics. Often values such as dignity and courage are highlighted. Fado's lyrics portrayed the typical daily life of the poorer neighborhoods of Lisbon, reflecting their concerns, fears, weaknesses and shortcomings but also their joy, celebration, neighborhood pride, hospitality and generosity (Mendonça, 2012; Pinto de Carvalho, 2003). Feelings are recurrent thematic references in Fado's lyrics love, jealousy, longing, betrayal, religious devotion - as well as its correspondent living contexts - the neighborhood, the street, the church, the procession, the party, the popular march, the bullfight, the toil of the sea (Coimbra de Matos, 2010a; Frydberg, 2012; Vieira Nery, 2004).

The lyrical content of Fado (and the corresponding instrumental composition) is emotionally rich, often referring to love, fate, longing, death, grief, melancholy, abandonment and helplessness. As Coimbra de Matos (2010) pointed out, "love is the brick and mortar of interpersonal relationships, the leaven of productive activity and the catalyst for creation" 
(p.115).

Singing such themes reinforces the national identity, either by the transgenerationality of the pain portrayed in these songs, or by the use of unique and untranslatable Portuguese words such as Saudade (as a mixture of memory and melancholy) or Fado itself (Frydberg, 2010; Mendonça, 2012).

Fado has always depended on its poetic content. In its historical origins in Lisbon, the narrative of the lyrics was often the subject of improvisation, either involving a single singer or in a "challenge" between two or various voices $-a$ bravado (Vieira Nery, 2004). It was first in taverns and later on in Fado houses that a triangulation of three participants a Fado singer, a classic guitar player and a Portuguese guitar player - has emerged. Any of these three musicians can be called Fadista, however this term is usually coined to Fado singers (Frydberg, 2010, 2012; Pinto de Carvalho, 2003).

Although there are several typologies in the classification of Fado, it can be divided in two main categories: Fado-Canção and Traditional Fado. Fado-Canção relates to an instrumental Fado with a poem as lyrics. It is recognized by the existence of a chorus, unlike Traditional Fado. Nevertheless, Traditional Fado is nowadays more valued as it is linked to the pursuit of a truer and more authentic Fado (Frydberg, 2010, 2012; Mendonça, 2012). The designation Traditional Fado has become generalized in recent years amongst the Fado community as a means to identify Fado(s) with strophes and to distinguish them from Fado(s) with a chorus. Some Fado singers prefer to limit their repertoire to strophic fados - such as the former Fadista Alfredo Marceneiro and more recently Aldina Duarte (Frydberg, 2012; Mendonça, 2012). Curiously, Amália Rodrigues (The Diva of Fado) and the musician Alain Oulman were in the 1960's the first to introduce classic Portuguese literature poems in Fado, in their pursuit for the lyrics quality (Lopes, 2012).

The history of Fado crystallized in the myth of the romantic involvement of Count Vimioso and Maria Severa Onofriana (1820-1846), a prostitute known for her singing talent and who would later become one of Fado's greatest Divas. The popularity of Severa resulted largely from her love affair with Count of Vimioso, which gave her great celebrity and allowed her a greater prestige and notability amongst of the young Portuguese intellectual elite. The aura of mystery that has turned Severa into the biggest mythological figure Fado remains today (Baptista, 2009; Brito, 1999; Pinto de Carvalho, 2003; Vieira Nery, 2004).

"The poor girl was such an interesting Fado singer as the Moorish quarter will ever see! ... It will not be easy for another Severa to come along as haughty and impetuous, as generous as a bully! Brave, full of affection for those she estimated, as was rude towards her enemies. She was no ordinary woman, rest assured".

Bulhão Pato (poet, in Monteiro, 1952, pp 102).

The Portuguese guitar is the element that best represents Fado; To hold a Portuguese guitar stands for being a Fadista. The Portuguese guitar is represented in all Portuguese cinematography with great emphasis. In the film "Fado - Story of a Singer", for example, a Portuguese guitar is lying on the table, as if this instrument and its music are as familiar and necessary as food (Frydberg, 2012). The first Fado house was founded in 1928 and the imagery of this musical genre began to emerge, with its symbolism and its communal space (the mystical ritual of Fado). It is when the institutionalization of Fado as a genre has happened that some basic rules on the performance of Fado were set, such as the need for absolute silence from the audience, the dimming of the lights, the banning of dancing and the definition of specific moments for applause and encouragement.

Amália Rodrigues, another iconic Fadista, also stood out for having introduced innovations in the posture and in the dressing of Fado singers that later became the rule, such as the systematic wear of a black dress and shawl for female Fadistas and the positioning of the Fado singer in front of the guitarists (Baptista, 2009; Brito, 1999; Tavares, 2009). Amália had a very unique body language: the head tilting back, the body swaying as she sang, the squinting eyes and the hands held on a prayer (Frydberg, 2010, 2012). The female Fadistas recreate on some level the image and the imaginary created by Amália and Severa, while male Fadistas recreate the one of Alfredo Marceneiro (hands on the pockets, the eyes closed and the head slightly raised). The representation of such performance is commonly incorporated in the gestures of younger generations, recurring to two forms of hand gestures: hands held together, as if on a prayer or hands held open along the body. Closing their eyes during a performance enables Fadistas to connect to their feelings - a requirement to sing certain fados. The gestures of Fado are performance elements that represent the fatalist internalization of what it is like to be a Fadista and how it feels like to sing Fado (Frydberg, 2012; Tavares, 2009).

"It's not Fadista those who want to, but only predisposed (...) as one can be born a poet, one can also be born a Fadista"

Amália Rodrigues (Fadista, in Frydberg, 2012, p. 422) 


\section{Saudade: In the Recesses of Depression and Depressiveness}

Some authors theorize about the relation among Saudade (a longing recollection), sadness, depressiveness and depressive syndrome prior to a careful examination of what that relation exactly is. This section attempts to clarify what that is, questioning the most problematic connotations between Saudade and Depression. It is true that, where there is Saudade there is sadness; It is also true that when looking at the clinical aspect of depression, sadness is one of its more prominent features.

Even though usually profound, sadness alone is an insufficient condition for a diagnosis of depressive syndrome (Coimbra de Matos, 2001) ; Oftentimes, the most critical complaint is a pervasive lack of interest in everything. Depressed subjects also exhibit severe inability to find pleasure in the company of others; In their love and sexual lives, in their work, in hobbies or social activities and in the mere act of imagining the future. Pleasure in evoking the past is, as a rule, also absent in depressed subjects.

The differentiation between the kind of recollection performed by depressive subjects (depressive evocation) and the kind of recollection outside depressive contexts shows - empirically - what clinical practice clearly indicates: longing recollection is by no means typical in depressed patients. An alternative explanation (one that does not, however, invalidate others) is that, it is the depressive mood; That it is, sadness itself that tends to deprive memory from congruent experiences (Amaral Dias, 2012; Figueiredo, 1991).

Studies presented in the examined literature support the hypothesis that Saudade is uncommon in depressive states and even less common in depressive syndrome (Figueiredo, 1991). In itself, i.e., independently of memories associated with past experiences, an unhappy mood or state of depression is likely to cause unhappy recollection - a kind of evocation patently different from that of longing recollection (Neto \& Mullet, 2014).

Depression favors recollection of bad experiences. It is to operate at a loss, to endure an inner nightmare. It is separation from the love object without the comfort of feeling one was loved, without gratifying memories of self-love. It is a past that denotes despair rather than confidence in the future (Coimbra de Matos, 2001: Cristiano Sousa, 2013). In contrast with it, the "anti-depressive" ability of Saudade reveals itself in all its splendor (Coelho, 2014). It operates by itself. It is a source of inner satisfaction (Bulat Silva, 2012), always available in memory. Its agency brings new meaning to the past. The subject's internal and external realities are altered, and both are contemplated from a standpoint of hope in the future (Coelho, 2014; Figueiredo, 1991; Teixeira, 2006).

\subsection{Amália Rodrigues' portrait - A Diva of Fado and Saudade}

Amália loved to laugh and to cry. Everything else seemed useless and alien to her; Strange and unnecessary. Everything else seemed to her to disagree with herself. As such, she lived at night, which was the time when she became closer to herself and to those she loved. Her day was a preparation for the night (Dos Santos, 2009 ; Tavares, 2009). She woke up late, did not eat much, did not focus on any particular task, and would occasionally go incognita to Monsanto Park (National Park in Lisbon) to pick up flowers. As night grew nearer, she drew herself to her full height, became even more beautiful and of sharper intelligence - she, who was highly intelligent (Coelho, 2014).

Despite appearances, Amália knew perfectly well what she wanted, and what was best for her. During those nocturnal hours, under the distant and placid gaze of her husband, she attended to her life and art (Freydberg, 2010, 2012; Pinharanda, 2009). She entertained guests and friends, caught up on news and gossip, scheduled shows, tried on dresses, prepared records, chose poems, tested musical compositions and every once in a while she sang. Evening gatherings at her place were a cross between an aristocratic soirée, a Fado house, a temple of adoration and of curiosity and a theatre stage. She performed "the role of Amália" (Dos Santos, 2009: Pina, 1986: Tavares, 2009) and her guests performed "the role of her audience" - loving her, admiring her, looking at her, listening to her all night long (Baptista, 2009: p.88).

She revisited memories, evoked people, made wishes, voiced complaints, whispered desires (Pinharanda, 2009). No sooner had she hinted that she wanted something then people ran to make it happen, although she pretended she was not aware of the causal connection; Everything was owed to her and, thus, everything occurred naturally. And she was right: that singular manner she had of becoming what she in fact was, that voice that was of everybody's when in fact it was hers, entitled her to anything and to it all. Even to die.

She spoke of death with a "Posthumous Saudade" of herself (Dos Santos, 2009, p.36). She would say that she was not afraid of dying, only of suffering. Amália, who was of the tragic genre, would on such occasions exchange it for dramatic talent. She knew life was dangerous and for that reason, she used to knock on wood three times. Her superstition, which was constant and ran deep, was manifested on refusals, rites, prayers, renunciations and signs. And her devotion was inseparable from a pact with the divine (Freydberg, 2012).

She became known in international arenas but like all great artists, she was loneliness' best friend (Dos Santos, 2009, p.37), running away from it, as if from an invincible enemy (Pinharanda, 2009: p. 310). She lived surrounded by people, 
hemmed in by voices, feelings, sayings, longings. She ruled the "court" around her - a queen seated in the throne of her voice (Coelho, 2014). When it suited her, she pretended not to hear what she was being told, she postponed resolutions with affected indifference; She turned blind, deaf and mute. Other times, people would be caught by surprise unaware of her arbitrariness, wisdom or acuity.

Like any other person that constructs and destructs herself daily, baring and hiding herself, Amália was egocentric but also insecure (Baptista, 2009: p.124). She liked to get to herself through others. They were her most faithful mirror; A mirror upon which she confirmed, recognized, recovered and renewed herself (Tavares, 2009). She forgave her friends everything except their abandonment, which was, in her view, the utmost expression of treason. But she would always try to regain the "estranged other" back out of friendship and dedication.

Everything in Amália made her turn over the gravity of life. That was her genius and her condemnation. It was her flight and her plunge. Perhaps this is why she would - in everyday gestures, in every hour words - attempt to claim a lightness that allayed the weight of fatum, the weight of Fado. She assumed life as fatalism, darkening her life of public glories with inner loneliness (Caiado Gomes, 2010; Baptista, 2009; Belo, 2012; Vieira Nery, 2004).

It was thus that Amália hid from sadness and loneliness: longing for herself, with Saudades of herself - for she was a queen only when she was seated in the throne of her voice (Coelho, 2014). If one "wants to be Fadista", Amália Rodrigues would say, one has to hold "Fado in one's senses"... and "sadness in one's heart" (Freydberg, 2012, p.424).

\section{The Voice of Fado - Voice Analysis of A Fado Singer}

The voice constitutes itself as an individual characteristic, much like a fingerprint, that is not repeated on any other individual. It reveals aspects of one's personality and sensibility. The voice is the tact of communication - it touches others as to convey ideas and emotions (Simões, 2014). In fact, when one is happy one tends to use a higher voice frequency, a stronger intensity and to speak faster. On the other hand, when one is sad a serious tone and a speech pattern with a slower pace are adopted. The voice also changes according to the intent of what is being said and to whom it is spoken (Panico, 2005; Rodrigues, Vieira \& Behlau, 2011).

Given that the emotions have specific physiological patterns, emotions, just like in the speaking voice, disrupt breathing, sound source, articulation and resonance; That is, the vocal tract as a whole is affected, though not equally for all the emotions - technical performance results are therefore affected by this ratio (Behlau; Feijo, Madazio, Rehder, Azevedo \& Ferreira, 2005; Frydberg, 2010, 2012; Rodrigues, Vieira \& Behlau, 2011).

Stage emotional communication is crucial for the quality of the singer performance and crucial to the degree of talent assigned to the interpreter (Simões 2014). While it is assumed that the technique is gained over the years, talent is supposed to be something innate that cannot be taught.

Young Fado singers seek in tradition their affiliation as an attempt to revitalize and at the same time to preserve the heritage of Fado. This affiliation happens by choosing a certain singer from a previous generation as a projective identification role model. The qualities of such a role model are copied, like the way of singing, the gestures and the dress code. This transgenerational contact teaches, through projective identification, what is "being Fadista" all about. Amália Rodrigues is undoubtedly the most important reference for the newer generation of Fado singers in the choice of repertoire, singing style or stage performance (Frydberg, 2012; Vieira Nery, 2004). Learning Fado and its formal characteristics as a unique and genuine Portuguese musical genre is related to having technical knowledge about the history of Fado, about the poetry of the Fado narrative and about its style (Frydberg, 2010, 2012).

“(...) traditional Fado has this feature, the melody is one, but then the Fadista gives it a very personal touch. The same Fado sung by two different people sounds like two different Fados (...). So these are the details that we learn over the years and I have been fortunate to have had people that have taught me (...)".

Raquel Tavares (Fadista, in Frydberg, 2012, p.408)

To be Fadista is to transmit a singer's legacy that surpasses music, involves professionalism and especially the construction of an identity linked to Fado that can only be learned through the direct contact between different generations of Fadistas (Frydberg, 2012). The audience also plays a role in mirroring the Fadista, in creating a group identity, in the sense that both recognize each other as participants on the same stage. While the vocal technique of Fado can be learned by listening to other singers, learning to be "Fadista" is much more difficult and complex than learning to sing Fado (Frydberg, 2010, 2012). It is based on the premise of emotion and valorization of one's sensitivity that each Fadista's repertoire is created and consolidated within their artistic career (Mendonça, 2012; Ribeiro de Carvalho, 1982).

"Yes, of course we have to feel it. There is no doubt. We cannot be actors or actresses completely (...)"

Joana Amendoeira (Fadista, in Frydberg, 2012, p. 410) 
Being a Fadista of the soul involves plenty of elements that go far beyond the vocal feature; It is required to express the soul in the voice and especially in the way of singing (Mendonça, 2012). In Fado, the vocal technique is only valued along with the visible and audible presence of the Fadista soul (Frydberg, 2010, 2012). Thus, it is preferable to have a voice technically inferior, but that expresses more emotion and more of a Fadista soul in connection to the social and symbolic universe of Fado.

“(...) Often foreigners do not understand our language, do not understand what we're saying, but they understand the music and our expression (...) Often foreigners need not to understand what we are saying because we sing it with our faces (...) We sing it with our faces, we sing it with our hands(...)They feel our souls, they feel the music that is most often sad, but also joyful.

Lina Rodrigues (Fadista, in Frydberg, 2012, p. 421)

One can think that to be a Fadista is a personal and artistic choice, but to be a Fadista is not really such - it is a Fado, a destiny imposed; There is no way to escape from it. To assume that «it was fate» that was at the heart of the Fadista's choice is part of the popular imagination as etymologically as the word Fado also means fate (Frydberg, 2010, 2012). Amália's voice was undoubtedly a unique and beautiful instrument, but what has captivated the audience was rather the prodigious capacity of her voice to serve as a vehicle for the drama and the pathos of poetic expression.

"It is the touch of the souls and the dance of the souls that make us love the song of life and dream about the poetry of the infinite"

Coimbra de Matos (2010b, p. 200)

\section{Trauma and the Sublimation of Helplessness in Fado}

Raubolt (2008) defines trauma as a series of experiences that are beyond one's ability to be integrated within in a way that allows one to function as one normally would. The power of adaptation is crushed, the meaning of life disappears and the brutality of human malfeasance is revealed. Victims of a relentless trauma have their creativity stolen and forced to verbalize an endless repetition of stories about themselves that have been demanded of them. These are actually the stories of the aggressor and the victim gradually becomes the ghost of his own empty body. But these are the stories that one has to pay attention to and honor, so that wounds can heal. By telling stories, repeating, talking and reflecting, one can restart life.

Could Fado serve as the sublimation of helplessness for those who sing it? How is trauma portrayed in Fado? What themes would better serve as a bridge between the inner and outer world? By analyzing the lyrics of Fado could one trace a psychological profile of those who wrote it?

\section{“With what voice?” *}

With what voice will I cry my sad fado,

that in such hard passion has buried me.

That long may not be the pain that time has left me, my

hopeless love.

But crying does not help this state

where sighing never had purpose.

sad I want to live, for it has changed into

sadness all the joy of the past.

So I spend life unhappy,

To the sound of this hard prison shackle that moans to the foot that suffers and feels it.

Of so much evil, the cause is pure love,

because of whom I have missing from me, for whose life and belongings I long for.

* Lyrics of Luis Vaz de Camões, music of Alain Oulman and voice of Amália Rodrigues

It is understood in the lyrics of this poem that the poet suffers from unrequited love, which forsakes and kills him internally. Joy is transformed into sadness and days are spent in a state of pain that imprisons the lover. He is stuck in love, but also for love. His sweetheart has been a replacement for his own internal object and without the beloved one he 
does not exist as a person and he feels depleted of any life plan. He remains a slave to the pain that pins his chest down, not knowing how to set himself free.

One can suggest a link between the type of loving relationship that the poet has lived with his primary object relationship and the one he recreates in his current love relationships. He may resort to compensatory idealization for his inner balance, because of his need for an object anchor and as a way to heal the narcissistic injury he has suffered. This mechanism can restore the denigrated image of a cold and distant object - unloved but essential to survival - that is deified in order to become worthy of the poet's love - a love he needs to give (Coimbra de Matos, 2001, 2010a, 2010b).

Subjects with secure attachments normally deal with their first love in a way that makes them attentive to the other person without the feeling of engulfment and therefore do not feel love losses as traumatic. In the euphoria, as in sadness, these individuals remain true to themselves. The same is not the case for most people with insecure attachments. The loving ecstasy triggers an anxious dilemma which they have difficulty to articulating. Hurt by their first love they are often afraid to love again. Love tastes bittersweet, as they often give too much and keep too little for themselves. The inability to establish a secure emotional relationship and the imminent expectation of separation has taught these adults to live in the anguish of loss, to relieve trauma once again (Ferreira, 2014; Raubolt, 2008).

When object idealization is reactive and compensates for the absence of tenderness and affection in the primary relationship, the nostalgia for an affectionate relationship, the appeal of regression and the need for comfort lead to the occurrence of a depressiveness trait in the individual, as it is shown in the present poem (Coimbra, 2001; Ferreira, 2014).

Fiction has a great relational value because the story narrated connects the speaker to the listener. Such is the magic of Fado, connecting Fadistas to their audience. The Fadista recreates the song's universe by singing it, in a complete surrender to Fado (as his fate) and to the audience.

When the traumatized subject, finds a person (or a group of people) to whom address the representation of what has happened, he begins to regain control of his own story. This process is slow because the healing of the traumatic wound requires a succession of trials and attempts. The traumatized person must learn to express pain in an acceptable manner and to find his own communication style. When a certain distance from the traumatic event is gained, allowing its intellectualization and keeping afar the turmoil of emotion it can be transformed into something superior, bearable, sublime.

Indeed, it seems that the best cure for the traumatized is to be able to understand what has happened to them. Those who can turn into resilient adults have been helped to give meaning to their wounds. By remembering one's difficulties and turning them into a representation of images, actions and words can one interpret the traumatic fault (Coimbra, 2011, 2014).

Such is the role of Fado in the sublimation of helplessness and sorrow: to give meaning to the wound that has happened and through the narrative to gradually release the pain, turning it into communication, into knowledge and into art (Coimbra, 2014; Ferreira, 2014).

The narrative and the resilience can be seen as strategies to fight against helplessness. To share a traumatic event is to suffer a second time, unless that through the narrative, the organization of memories and the choice of words one finds a new control over his emotions and therefore correct the interior image of what has happened. Thus, a type of traumatic narration can be organized. Those who remain fascinated by the object that threatens them are kept prisoners, condemned to repeat the same story. On the other hand, those who express a split narrative, witness the onset of a resilience process that will set them free.

The narration is not simply a return to the past. The ability to account for one self is necessary to build an image of one's own personality. This reporting process has two functions: one of identification and one of emotional remodeling (Outeiral \& Godoy, 2003). They function like an equivalent of a secure attachment when such was not available in infancy.

The narrative allows the person to constitute himself as intimate subject and to take his place in the human world, sharing his story. Such is Fado: an intimate narrative of the poet and/or of the Fadista, sharing their story to their audience, their people them (Ferreira, 2014; Raubolt, 2008). Fado is but a form of resilience (Cyrulnik, 2003) in the sublimation of helplessness, a fight against the omnipotence of trauma (Outeiral \& Godoy, 2003; Raubolt, 2008). Fado seems to enable Fadistas to bridge over the suffering, like a ray of light in the darkness.

Through the Fado that the Fadista sings, by the tone of his voice, one can trace back possible scenarios of his developmental shortcomings, which can be analyzed and interpreted in the same way as the presented Fado lyrics. The audience can help the Fadista by offering possible meanings to his "performance" and by assisting in the narrative construction that creates a personal story and a relationship with others (Coimbra de Matos, 2010a; Ferreira, 2014). 
An event, in fact, is what one makes of it: despair or a glory. It is at the confluence of the inter-subjective worlds that the emotion attached to the event is born (the story of oneself, one's story of others, and others' story of oneself). These stories can be real or imagined without losing their strength as stories. What matters is for the story to have goal, for all stories are instruments that build one's world. And when one feels better because of the understanding of their purpose in the world, it is because this given meaning has transformed the absurd and chaos into reason and enlightenment.

"At the end of life, one in two people will have suffered an event that can be classified as a trauma, a violence that has left one close to death"

(Cyrulik, 2003, p. 161).

\section{Revisiting the Meaning of Saudade}

When experiencing Saudade one is in a state where consciousness opposes what life is currently offering. Specifically, one experience something already lived but currently absent. This notion requires the preservation of a cluster of emotionally interconnected representations (Amaral Dias, 2012; Borges-Duarte, 2012). The temporal aspect of Saudade is retro-tense: the proper tense of Saudade, the time frame where it dwells, is that of the already lived (Carvalho, 1986). It is determined by an act of evoking representations - a recollection without which the psychological process of Saudade could not develop.

Confronting current reality is extremely important. The perception of reality establishes the measure of the loss that one has suffered - and longs to reclaim (Figueiredo, 1991). It is a representation heavily impregnated with emotion. Consequently, experiencing Saudade is akin to a "spiritual perception" of a lived experience, coupled with the desire to relieve it (Carvalho, 1986).

The connection between Saudade and longing for people, times or places with whom, when or where an enjoyable moment was experienced is a constant (Bulat Silva, 2012). A gratifying recollection stimulates the desire to re-encounter, to repeat, and to create situations capable of reproducing that evoked pleasure.

Perception of current reality versus recollection of those moments is where one feels Saudade and gives the subject the internal, subjective dimension of their loss (Belo Gomes, 2010). Saudade is pleasure in evocation; And pleasure in evocation changes the very object that is evoked, which is now perceived in light of the current sentiment. Such evocation idealizes the past, as is the case when recollecting one's love object (Coimbra de Matos, 2010a). The process of idealization is preceded by the process of internal evocation - a psychological process made possible by Saudade (Figueiredo, 1991).

Saudade is not, therefore, a "passive file from the past" (Ferreira, 1986; Figueiredo, 1991) that is brought forth in present evocation; It is a reconstruction (Dias, 2014). Recollection "is a present element that acts upon the past"; It is a new way of experiencing the past. That is, as Amaral Dias (2012, pp.216) underlines, to remember (etymologically speaking), to feel with the heart one more time is of a spontaneous therapeutic nature, quite opposite from mnesic erudition.

By virtue of desire Saudade is also hope (Coimbra de Matos, 2010b; De Pascoaes, 1986; Dias, 2014; Figueiredo, 1991;): In Saudade, the future is the past, and the past is what provides meaning and content to the future. Loves, as well as recollection of love, induce powerful states of mind, capable of prevailing over despair (Graça Moura, 2010). These are intrapsychic experiences that keep alive one's hope that love will happen again. Saudade is powerful enough to overcome despair and sadness, and hope is a feeling intimately interconnected with it.

Saudade is characterized by its temporal dimension. Unlike simple nostalgia, Saudade resonates in the past, in the present, and in the future (Neto \& Mullet, 2014: Vieira, 2007). It is a past that, via desire, is hope and, as such, is also a present projection to the future (Figueiredo, 1991: Teixeira, 2006). The temporal dimension of Saudade is what distinguishes it, from the concept of pure nostalgia (Neto \& Mullet, 2014). The role of "internal healing" played by Saudade in grief and emotional loss by means of longing recollection, allows the burden of sadness and anxious love, to progressively shift into gratifying and comforting love. Sadness is the predominant emotion in grief or loss situations. Loss must have an emotional price; Its price is sadness, suffering and self-knowledge.

Longing recollection as internal healing of the mind serves the purpose of protecting the subject's internal confidence, thus making it again viable for that subject to invest in both their internal and external world. This is symbolically connected to the subject as the "presence of the absence" (Kampff Lages, 2002).

As mentioned earlier, we know that Saudade does not include the depressive syndrome (Neto \& Mullet, 2014). That said, it can be mistaken for it. The healing function of Saudade is also present in the drama inherent in the loss, departure or separation from one's love object, as it is present in sadness, in crying and even in death wishes (recognition). Saudade has a constitutive dimension of sadness - in Fado, sadness and Saudade are always attached to the separation of one's love object (Belo Gomes, 2010). The issue of Saudade emerges thus as an autonomous process that organizes the 
subject's psychological life (Coimbra de Matos, 2010; Figueiredo, 1991). As Figueiredo (1991, p. 73) points out, the repairing ability of Saudade is not only about evoking, but it also touches cores of sadness, hurt, inner turmoil, giving it a new emotional tone.

André Green (1973) points out that the role ascribed to absence is crucial to all psychoanalytical theory. Absence of the relational object brings about displeasure and the representations of both satisfaction and the object that determines it. In Saudade, we find all elements that, in the organization of desire, are associated with the absence of that object.

A twofold movement occurs: i) psychological investment of the longing imaginary and ii) investment in the external object that the subject longs for. Imaginary satisfaction - Saudade - plus dissatisfaction caused by absence stimulate the act of looking for the missing object, which re-encounter is assumed to trigger more pleasure than its mere representation. As such, imaginary and reality are jointly and complementary invested. It constitutes a psychic paradigm that simultaneously encompasses a syncretic experience (sadness) caused by one's awareness that the object of satisfaction is absent, and the satisfaction caused by recollecting the satisfaction directly obtained from the object (Saudade).

The "healing ability of Saudade" (Dias, 2014) seems to represent a link that protects the subject's psychological life against enduring loss experiences. Longing recollection fondly associates past pleasant experiences (Coimbra de Matos, 2010b: Frydberg, 2012), but reacts to loss of love, death, separation change in status and ageing with sadness.

Some Portuguese authors have absolutely no doubt, that the sentiment covered by the word Saudade is impossible to translate (no affective or verbal translation) - it is a genuine verbal symbol of the Portuguese soul (Caiado Gomes, 2010; Coimbra de Matos, 2010b; Frydberg, 2012; Lourenço, 1992). The universality of the longing experience Saudade - , however, is indispensable in structuring psychological life, where it acts as a primary/basic organizer. It allows imaginary gratification to be derived from one's relation both with reality and with one's imaginary life.

Memory's internal healing ability is paramount in our understanding of the psychotherapeutic effect of recollecting a longing past complete with longing - it reconfigures tormenting past experiences, mitigating them and facilitating the relation with a painful reality (Dias, 2014; Figueiredo, 1991,).

Coimbra de Matos (2014, Pers. Comm., 8 May) argues that the healing function of the mind conceives the direction of the cure: the (voiced) sigh meets the (silent) breath of long lost hope, now revived. Paraphrasing Camões' verse "imagine it, those who cannot experience it" (The Lusiad, book IX), we would say "conceive of it, those who have not yet experienced it". It is not the notion of "what could have been, but was not" (melancholy), rather "what has not yet been, but could be" (of conquest).

\section{Conclusion}

Fictional reality triggers a profound relational impact through the way the story links the speaker to the listener. Such is the magic of Fado, connecting the singer / musicians to their audience. The singer recreates the universe of song by singing it, in a complete surrender to Fado and to the audience. When traumatized individuals, hear embodied in the Fadista, they find someone to address the representation of their internal worlds and his - his Fado - especially as he begins to take control of his story. The wounded person has to learn how to express the pain of psychic wounds in an acceptable manner and his style (whether elegance, mannerism, scorn or humor) becomes the relational communication tool. The (re)interpretation through Fado of what the individual has lived, allows for the sublimation of trauma. Therefore, the connection and the meaning is what makes resilience possible and what enables the process of finding new paths after an experience lived as traumatic. In fact, it would seem there is only one solution for healing those traumatized: to understand what has happened and to give significance to their "traumatic faults".

Such is the power of Fado: an intimate narrative of the artist (who creates and interprets it), a product of popular culture that embraces performer and audience. Fado appears thus as a form of resilience in the sublimation of helplessness and as a sign of struggle against the omnipotence of trauma. And so does the "anti-depressive" ability of Saudade. The only pleasure of the artist is his imagination. It is possible to carve out a narrow bridge of resilience when the surrounding culture offers around the artist some contact interfaces. Fado seems to enable such in the imaginary of the Fadistas, creating a restorative bridge for the suffering - like a singular shaft of light in the dark night.

The lyrics of Fado intend to (re)create a space of communication with the listeners (the audience), inviting them to reflect, to counterpoint, to (re)think. An event, - a Fado -, is what one makes out of it: a despair or a glory, much like a phoenix rising from the ashes.

\section{Acknowledgements}

The authors would like to thank Richard Raubolt and Ana Neves for their providing language help, writing assistance and proof reading the manuscript. 


\section{References}

Amaral, D. C. (2012). Rememorar o Desejo, Conceder-lhe Futuro. Se..., Não! Revista de Psicanálise, Psicoterapia e Desenvolvimento Humano, 3(2), 211-220.

Baptista, T. (2009). Ver Amália: Os filmes de Amália Rodrigues. Lisboa: Tinta-da-China.

Behlau, M., Feijó, D., Madazio, G., Rehder, M. I., Azevedo, R., \& Ferreira, A. E. (2005). Voz profissional: aspectos gerais e atuação fonoaudiológica. In M. Behlau (Org.), Voz: O livro do especialista, 287-372. Rio de Janeiro: Revinter.

Belo, M. (2012). Destruição e Recriação: Dinâmica inevitável à vida. Se..., Não! Revista Portuguesa de Psicanálise e Psicoterapia Psicanalítica, 3(2), 263-282.

Belo-Gomes, M. (2010). Lutos, Perdas, Desafios e conquistas, na vida e no processo analítico. Se..., Não! Revista de Psicanálise, Psicoterapia e Desenvolvimento Humano, 1(1), 125-141.

Borges-Duarte, I. (2012). Memória e Desejo do Ponto de Vista Existencial. Se..., Não! Revista de Psicanálise, Psicoterapia e Desenvolvimento Humano, 3(2), 221-239

Brito, J. P. (1999). O Fado: etnografia na cidade. In G. Velho (Ed.), Antropologia Urbana: Cultura e Sociedade no Brasil e em Portugal, 24-42.

Bulat, S. S. (2012). Saudade: A Key Portuguese Emotion. Emotion Review, 4, 203-211.

Caiado, G. J. (2010). Matriz de Identidade e Mudança: O caso Português. Se..., Não! Revista de Psicanálise, Psicoterapia e Desenvolvimento Humano, 1(1), 49-65.

Carvalho, J. (1986). Reflexões sobre Teixeira de Pascoaes. In A. Botelho, \& A.B. Teixeira (Eds.), Filosofia da Saudade , 694-713.

Coelho, E. (2014). The Story of a Singer: In the recesses of depression and depressiveness. In M. Rosário Dias (Coord.), The question of (a) voice: with what voice I cry my sad Fado? Panel presented at the $25^{\text {th }}$ Annual Interdisciplinary Conference, IFPE, San Francisco, CA, USA.

Coimbra de Matos, A. (2001). A Depressão. Lisboa: Climepsi.

Coimbra de Matos, A. (2010a). O Jogo do Amor na Psicanálise e na Vida. Se..., Não! Revista de Psicanálise, Psicoterapia e Desenvolvimento Humano, 1(1), 115-124.

Coimbra de Matos, A. (2010b). O toque das Almas. Se..., Não! Revista de Psicanálise, Psicoterapia e Desenvolvimento Humano, 1(1), 199-200.

Coimbra de Matos, A. (2011). Relação de qualidade, penso em ti. Lisboa: Climepsi.

Coimbra de Matos, A. (2014). Se me implico transformo: desejo, criatividade e possibilitação. Conferência apresentada no III Congresso Internacional de Psicodrama Psicanalítico "Inquietude, Criatividade, Transformação", Março, Lisboa, Portugal.

Cristiano, S. N. (2013). Depressão e o sentido da imortalidade simbólica. Se..., Não! Revista Portuguesa de Psicanálise e Psicoterapia Psicanalítica, 4(2), 353-370.

Cyrulnik, B. (2003). O murmúrio dos fantasmas. Lisboa: Temas e Debates.

De Pascoaes, T. (1986). O espírito Lusitano ou o saudosismo (Expressão poética, filosófica e religiosa do saudosismo). In A. Botelho, \& A.B. Teixeira (Eds.), Filosofia da Saudade, Lisboa: Imprensa Nacional Casa da Moeda. (Originally published in 1963).

Dias, M. R. (2014) Saudade: With what voice will I cry my sad Fado?. In M. Rosário Dias (Coord.), The question of (a) voice: with what voice I cry my sad Fado? Panel presented at the $25^{\text {th }}$ Annual Interdisciplinary Conference, IFPE, San Francisco, CA, USA.

Dicionário da Língua Portuguesa. (2006). Lisboa: Texto Editores.

Dos Santos, J. (2009). Estranha forma de vida. In Museu Colecção Berardo (Ed.), Catálogo da Exposição Amália: Coração independente. Lisboa: Fundação Amália Rodrigues.

Ferreira, A. (2014). Trauma and sublimation of helpleness in Fado. In M. Rosário Dias (Coord.), The question of (a) voice: with what voice I cry my sad Fado? Panel presented at the $25^{\text {th }}$ Annual Interdisciplinary Conference, IFPE, San Francisco, CA, USA.

Ferreira, J. (1986). A Saudade, Nova Dimensão Psíquica do Homem. In A. Botelho, \& A.B. Teixeira (Eds.), Filosofia 
da Saudade, 334-350.

Figueiredo, E. (1991). Psicanálise da Saudade. Lisboa: O Jornal.

Frydberg, M. B. (2010). Alfama não cheira a fado, mas não tem outra canção' ou 'Tudo isso é a alma do Rio, é samba': As cidades Descobertas através do Samba, do Choro e do Fado. Ponto Urbe [online], Issue 6, July 2010, accessed 10 November 2015, http://pontourbe.revues.org/1560; HTTP://DX.DOI.ORG/ 10.4000/pontourbe.1560

Frydberg, M. B. (2012). “O fado que nós cantamos, é a sina que nós seguimos”. Jovens Fadistas portugueses e a emoção como meio de se construírem enquanto artistas. Revista Brasileira de Sociologia da Emoção, 11(32), 390-426.

Graça Moura. V. (2010). O caderno da casa das Nuvens. Lisboa: Edições Afrontamento.

Green, A. (1973). Les Discours Vivant. Paris: PUF.

Kampff Lages, S. (2002). José Guimarães Rosa e a Saudade. S. Paulo: Editora Atelie.

Lopes, S. (2012). Fado Portugal - 200 anos de fado. Lisboa: SevenMuses Musicbooks.

Lourenço, E. (1992). O Labirinto da Saudade: Psicanálise Mítica do Povo Português. Lisboa: Dom Quixote.

Mendonça, L. F. (2012). O fado e "as regras da arte": "autenticidade", "pureza" e mercado. Sociologia, Revista da Faculdade de Letras da Universidade do Porto, 23, 71-86.

Monteiro, J. (1952). A estrada de Sacavém. Lisboa: Edição do Grupo "Amigos de Lisboa".

Neto, F., \& Mullet, E. (2014). A Prototype Analysis of the Portuguese Concept of Saudade. Journal of Cross-Cultural Psychology, 45(4), 660-670.

Outeiral, J., \& Godoy, L. (2003). Desamparo e trauma: transferência e contratransferência. Rio de Janeiro: Revinter.

Panico, A. C. B. (2005). Expressividade na fala construída. In L.R. Kyrillos (Org.), Expressividade: da teoria à prática. Rio de Janeiro: Revinter.

Pina, L. (1986). História do cinema português. Mem Martins: Publicações Europa-América.

Pinharanda, J. (2009). À procura de um rosto. In Museu Colecção Berardo (Ed.), Catálogo da Exposição Amália: Coração independente, 303-313.

Raubolt, R. (2008). Theaters of Trauma: Dialogues for Healing. Bloomington, USA: iUniverse.

Ribeiro de Carvalho, J. P. (1982). História do Fado. Lisboa: Publicações Dom Quixote.

Rodrigues, G., Vieira, V. P., \& Behlau, M. (2011). Saúde vocal. São Paulo: Centro de Estudos da Voz. Available in: http://www.cevfono.com

Simões, N. (2014). The voice of Fado: Voice Analysis of a Fado Singer. In M. Rosário Dias (Coord.), The question of (a) voice: with what voice I cry my sad Fado? Panel presented at the $25^{\text {th }}$ Annual Interdisciplinary Conference, IFPE, San Francisco, CA, USA.

Tavares, E. (2009). A imagem da voz. In Museu Colecção Berardo (Ed.), Catálogo da Exposição Amália: Coração independente, 195-213.

Teixeira, A. B. (2006). A Filosofia da Saudade. Lisboa: QuidNovi.

Vieira, E. (2007). "Saudade" and "Soledad": Fernando Pessoa and Antonio Machado on nostalgia and Loneliness. Romance Notes, 48(1), 125-133.

Vieira, N. R. (2004). Para uma história do Fado. Lisboa: Público.

Notes

This manuscript has been based on the panel entitled, "The Question of (a) Voice: With what voice will I cry my sad Fado? “, presented at the IFPE 25th Annual Interdisciplinary Conference held at San Francisco in 2014.

\section{$(\mathrm{cc}) \mathrm{BY}$}

This work is licensed under a Creative Commons Attribution 3.0 License. 